New Zealand journal of industrial relations, 1984, 95, 95-112

\title{
Full circle: Australian wage determination 1982-1984
}

\author{
David H. Plowman*
}

This article, the third by the author for this journal, follows trends in Australia wage fixing from December 1981 to mid-1984. It deals particulary with the effects of the Hawke Labour Government's economic policies as they have affected wage determination and attempts to assess possible future developments.

Two previous articles in this journal outlined the operations of the systems of wage indexation which operated in Australia from April 1975 until July 1981 (Plowman 1978, 1982). These articles examined the changing political and economic context within which indexation operated, the 19 different National Wage Cases conducted over the period, the increasing pressures placed on centralised wage fixing, the 5 separate sets of guidelines which attempted to take account of prevailing circumstances, and the final breakdown of the system. The second article also examined the metal industry settlement of December 1981 which provided the benchmark for award adjustments in 1982 .

This article documents developments in the period following the Metal Industry Agreement of December 1981 to the middle of 1984 . This brief period of some $2 \frac{1}{2}$ years witnessed attempts at "decentralisation", the imposition of the only explicit wages freeze in Australian federal history, and the return to wage indexation. The first part of this paper briefly reviews the system of decentralisation operating in 1982 as well as the May 1982 National Wage Case in which the ACTU sought a return to centralism. The second section examines the wages freeze introduced in December 1982 together with the probable reasons for the Coalition Government abandoning its apparent faith in the case by case approach to wage determination. The third section documents the new Labor Government's economic prices and incomes approach to economic management, the ALP ACTU Economic Accord and the National Economic Summit Conference, all of which set the scene for a return to centralised wage determination. The penultimate section reviews the return of indexation, the guidelines adopted for the period to September 1985 , and the National Wage Case of April 1984. The final section examines potential future developments and possible pressures on the Accord and indexation, and the Liberal Party's new wages policy. This section serves to confirm the general conclusion of the previous article, namely that "over the long haul, the Australian approach to wage determination may come to mirror the political cycle".

\section{Decentralisation}

The period of so-called decentralisation prevailed from the end of indexation in July 1981 until the commencement of the wages freeze in December 1982. Wage settlements

* Senior Lecturer, Department of Industrial Relations, University of New South Wales. 
in this period were influenced by the Metal Industry Agreement of December 1981. The implementation of the freeze prevented a renegotiation of this Agreement and thus its potential as a further pace-setter. The National Wage Case of May 1982, in which the ACTU sought to establish the Agreement as a community standard together with a return to a centralised system, was the major interlude of the period.

\section{The National wage case, May 1982}

As noted in the 1978 article the Metal Industry Agreement provided for a $\$ 25$ per week increase at the fitters rate (i.e. 11.9 percent for New South Wales tradesmen), a \$14 mid-term adjustment (5.7 percent), increased supplementary payments, a reduction in working hours from 40 to 38 per week, and a "no further claims" clause. In this National Wage Case the ACTU sought to establish the terms of this Agreement as a community standard. It argued that since the Agreement had been concluded there had emerged a movement in wage rates of similar or identical proportions to those of the metal agreement and sought an arbitrated follow-on to those employees not already in receipt of this standard. In this respect the union claim appeared to differ from other national wage claims in which generalised wage increases are sought on the grounds of economic capacity. To the extent, however, that the mid-term adjustment did not have general application in May 1982, the ACTU claim was effectively one of the $\$ 25$ "catch-up" (in proportional terms) plus a $\$ 14$ per week wage increase.

In considering the claims the Commission considered 2 major questions as paramount. The first concerned whether or not the Metal Industry Agreement did in fact constitute a "community standard". The second consideration was whether or not it should provide for a centralised system of wage determination or continue with the "unguided case by case approach" requested by both the government and private employers. The government argued that its non-accommodative economic policy, particulary tight monetary controls, would ensure wage demands were kept in check, particularly once the "learning costs" accompanying the movement to the decentralised system had been overcome.

The case was conducted in the background of economic recession. The Metal Agreement of December 1981 had been concluded in the prevailing "economic boom" environment. This rapidly gave way to an environment of "economic doom". Whereas metal establishments had full order books at the time of the Agreement as well as heightened expectations, a sudden and serious downturn resulted in the industry suffering its worst recession since the depression of the 1930 s. Within a short period the metal unions which had successfully negotiated a shorter standard working week were attempting to obtain the short-term week to protect job opportunities. The short-term week is one in which both hours of work and wages are reduced to accommodate the work in hand. This economic downturn may have been the reason for the ACTU's application. Though it was entitled to apply for such a case in February, at a time when flow-ons through negotiations were more easily achieved, it choose not to do so until April, by which time negotiations were more difficult. The economic context necessitated the ACTU presenting arguments concerning the capacity of the economic to pay its "catch-up" claims. This it attempted by asserting that the Metal Industry Agreement did little more than compensate for price increases in the 18 month period from the abandonment of indexation to the expiration of the Agreement. For good measure the it added that "known productivity increases since 1974/75 are accommodated in the catch-up application".

This latter claim had less merit than may appear the case, notwithstanding the provisions in the indexation guidelines for national wage adjustments on the grounds of national productivity and the fact that no such claims were processed. The generalised 4 percent "work value" wage round of $1978-80$ was more in the nature of a productivity rather than a work value wage movement (Plowman, 1981, pp.105-7).

The Confederation of Australian Industry (CAI) had the better of the economic argument on this occasion. Its evidence suggested that the labour cost increases resulting 
from the Metal Agreement amounted to between 20 and 30 percent depending upon the base chosen. Increased overtime resulting from the shorter working week could increase these estimates by a further 3 percentage points.

Though it expressed reservations concerning this and other statistical information presented, the Bench concluded that there had been large earnings "compared with normal national productivity movements (which) may have a delayed adverse effect on profitability, employment and inflation - especially in the context of the non-accommodating economic policy of the Commonwealth and the deterioration in Australia's international competitive position" (ACAC 1982a, p.11).

The Commission was also cautious concerning the existence of a community standard. After dissecting the statistical evidence it concluded that over 80 percent of all award employees had received wage increases since the abandonment of indexation. Of these between 88 percent and 91 percent (depending upon whether one accepted CAI or ACTU calculations) had received increases of $\$ 20$ or more. Only a third of the ACTU sample, however, had received $\$ 20$ or more as well as the mid-term adjustment. The Bench concluded that "the search for a community standard ... has not been conclusive and we are not prepared to recognise the existence of the specific standard sought by the ACTU" (p.15). Such a standard was explicitly recognised 6 months later when the Government sought the introduction of the wages freeze.

The full Bench also refused the ACTU claim for a return to a centralised wages system in favour of the existing system supported by the Government. In doing so, however, it left the Government in no doubt about its disquiet concerning the approach sought:

... we are not as sanguine as the Commonwealth about the force of learning experience in the present circumstances. We note that despite the Commonwealth's non-accommodating economic policy settings which it said "had been in place for some time", the level of wage rates has risen sharply in the various settlements which have occured since the abandonment of wage indexation; and they have affected a variety of industries, including those which are not in a strong competitive position in relation to imports such as clothing, textiles and motor vehicles. We note that employers have expressed a contrary view of the efficacy of nonaccommodating economic policy and the monetary bite in restraining the size of wage settlements... The monetary bite may eventually operate in the labour market but from our observations and experience of wage settlements, it could take much longer and inflict greater economic and industrial hardship than the Commonwealth appears to assume (p.25).

Apparently the Government itself came to a similar conclusion. Within 6 months of the decision being handed down it sought the abandonment of the case by case approach in favour of the most centralised wages system ever implemented in Australia - the wages freeze.

\section{The Wages Freeze}

The Metal Industry Agreement was to expire in December 1982. Metal unions drew up an ambit $\log$ of claims which suggested the potential for a further round of increased labour costs for this industry, and for other industries the subject of flow-ons. This claim included the full indexing of wage rates at the December 1982 levels, increased supplementary payments, a 9 day fortnight, the payment of basic health cover of employees by employers, an increase in overtime rates and sick leave entitlements, the indexing of tool allowances, paid study leave, and an increase in clothing provisions. A reasonable assessment at the time was that the unions would have settled for full indexation (Plowman, 1982, p.201). The MTIA responded by seeking a continuation of the existing agreement for a further 6 months, thus resulting in a freezing of wages for this period. The Government took up this cue, no doubt by now conscious that a new wage round eminating from a new agreement may not have been constrained by its "non-accommodating policies" nor by the surmounting of "learning costs". In that month it legislated for a 12 month wage 
freeze for its own employees by way of the Salaries and Wages Pause Act 1982. Under this legislation wage tribunals were unable to increase rates of remuneration for public employees. At a Premiers' Conference in the same month the Government was able to pursuade the states to support such a freeze in relation to their own employees, the carrot being that any money thus saved would be given to the states for employment relief projects. The Commonwealth estimated this saving to be in the order of $\$ 300 \mathrm{~m}$ over the 12 month period.

The Government sought an extension of the freeze to the private sector by way of a National Wage Case which concluded on December 23. Generally the states supported the Commonwealth in its application for a wages freeze, though 3 (Labour) states sought a 6 month rather than 12 month freeze. Private employers also supported the freeze urging the Commission to declare that the national economy could not support any increases in labour costs. They proposed that a national inquiry be held at the end of the 12 month period to determine whether or not the freeze be removed. Not unnaturally the ACTU strongly opposed the wage freeze claiming that there was no benefit to either industrial relations or to the economy in such a move. It further claimed that a wages freeze which was not accompanied by a freeze on prices was inequitous.

The Commission's assessment was that the wages pause should be extended to the private sector. It choose, however, to initiate a freeze for only 6 months and to review the situation in June 1983. Further action would be determined on the outcome of this review. The Bench determined a set of guidelines for the duration of the freeze which noted that:

a policy of restraint should apply to any proposal for an increase in wages, salaries or allowances, reduction of hours, or improvements in other conditions of employment, whether by award, overaward or agreement. The Commission will guard against any contrived arrangement which would circumvent this approach (ACAC 1982b, p.15).

In summary form the guidelines provided that:

(1) There should be no increase in wages and salaries of federal awards.

(2) Awards which had not received the "metal industry standard" could be varied up to this standard.

(3) Where new processes or method of work were introduced warranting the creation of new classifications of employees, new award rates of pay could be established.

(4) Application being processed in the Commission for the introduction of a 38 hour week could proceed under the rules adopted in May 1982. No new applications were to be processed.

It is interesting to speculate on the reasons for the Government's decision to abandon the case by case approach in which it had previously placed such great faith. One reason may well have been the replacement of Viner by Ian MacPhee as Minister for Industrial Relations. The former was a "dry" enarmoured by the virtues of collective bargaining. MacPhee is a past member of the "industrial relations club", having been Director of the Victorian Chamber of Manufacturers for many years. MacPhee lost little time in voicing concern for the system then in operation.

A more compelling factor in the Government's volte-face may have been political expediency. An election was due by November 1983 and economic analysts predicted that the economy would deteriorate further by then. The August 1982 budget was generally regarded as an early election budget. The election was delayed because of the Costigan Report which indicated gross irregularities in certain offices of the Taxation Department. The wages freeze may well have been designed to bring about union hostility, strike action and a "law and order" election. If so, the strategy failed because of poor timing. Fraser called the election at a time when industrial action in the petroleum and transport indus- 
tries over the freeze had not reached the point of no return. Unions were able to call off their industrial action and so minimise any potential harmful effects on the ALP's election prospects. For its part the ALP was able to convert the election issue into one over economic management, an area in which the Coalition Government was suspect. Labour was elected with a resounding majority in March 1983.

\section{Labour and the consensus approach}

Labour campaigned under the election slogan "Let's All Pull Together", a slogan which attempted to contrast its "consensus" approach with the "inflation first" and devisive approach of the Coalition. Two major elements of vital bearing upon wage determination formed a part of this Labor strategy. These consisted of the Accord, an agreement between the ALP and the ACTU signed during the election period, and the National Economic Summit Conference held shortly after winning office.

\section{The ALP-ACTU Economic Accord}

During the period of Opposition the ALP developed and refined its economic policies. The major thrust of economic management under these policies is one of combating inflation and unemployment simultaneously by way of a prices and incomes strategy. The experience learnt during the Whitlam period in which there were frequent policy differences between the industrial and political wings of the labour movement led to the establishment of a joint ALP-ACTU body, the Australian Labour Advisory Committee (ALAC). The Accord was a major outcome of the deliberations of this Committee consisting of 3 ACTU members and 3 ALP members. The latter included Hawke the present Prime Minister, Hayden then leader of the Opposition and now a senior Cabinet Minister, and Willis who is now Minister for Employment and Industrial Relations.

The Accord argues the cases for a prices and incomes policy; spells out the nature, and defines the elements of, such a policy; and outlines the policy details agreed upon between the ALP and the ACTU. Concerning the need for a prices and incomes approach to economic management the Accord notes:

It is with (the monetarist) experience in mind that both organisations have seen fit to try and develop a mutually agreed upon policy on prices and incomes for implementation by a Labour Government. Such a policy offers by far the best prospects of enabling Australia to experience prolonged higher rates of economic and employment growth, and accompanying growth in living standards, without incurring the circumscribing penalty of higher inflation, by providing for resultion of conflicting incomes claims at lower inflation than would otherwise be the case. With inflation control being achieved in this way, budgetary and monetary policies may be reasonably set to promote economic and employment growth, thus enabling unemployment to be reduced and living standards to rise. (ACTU, 1983, p.2).

The agreed upon policy details provide for "wage justice" and the ensuring that "wage increases do not give added impetus to inflation or unemployment". It is agreed that:

- A centralised system of wage fixation is desirable for both equity and industrial relations reasons ...

- To protect the purchasing power of wages and salaries the adoption of a system of full cost of living adjustments will be strongly supported...

- Wage and salary earners may share in increased national productivity through either increased real incomes or reduced hours of work, or an appropriate combination of both.

- In formulating (wage) claims .... unions will have regard to Government economic policy and will consult with the Government on the amount of such claims.

- Both parties recognise that if the essential conditions of the centralised system are met that there shall be no extra claims except where special and extraordinary circumstances exist... (p.5). 
The agreed upon policy also provides for the establishment of a pricing authority; the strengthening of the Trades Practices Act to strengthen and promote effective competition; controls over non-wage incomes including dividends, capital gains, rent, interest, directors' fees, and incomes of unincorporated enterprises; restructuring of the income tax scale to ease the tax burden on law and middle income earners; measures to smash tax avoidance; reduction in regressive indirect taxation; and the development of "supportive policies" in a range of areas. These include industrial relations legislation, industrial development and technological change, immigration, social security, occupational health and safety, education, health, and public employment.

Thus it can be seen that the Accord is an all-embracing document. Of particular interest for the purposes of this paper is its support for the centralised system of wage determination based upon (full) indexation.

\section{The National Economic Summit Conference}

Just as the Accord was designed to cement ALP-ACTU relations so the Economic Summit, which took place during 11 - 14 April, was designed to project the "consensus" approach to business and other community interests. The scene for the Summit was largely set by Teasurer Keating who outlined the principal guidelines which would direct ALP economic strategy. As might be expected these guidelines closely followed the Accord and in some cases where identically worded as the Accord. The thrust of Keating's approach was that:

(1) Without a prices and incomes policy, economic recovery would soon lead to increased inflation, thus forcing the Government to adopt contractionary anti-inflationary policies which could truncate recovery.

(2) A prices and incomes policy permitted higher rates of economic growth, without incurring the circumscribing penalty of higher unemployment and inflation.

(3) Within the context of an incomes policy, budgetary and monetary policies could be responsibly set with an eye to economic growth.

(4) While the prices and incomes policy would allow the Government to stimulate the economy and thus reduce unemployment, Government could see no quick solutions available for a return to full employment.

The Treasurer then presented 3 scenarios variously called Scenarios A, B and C, or High, Medium and Low Wage Economic Paths respectively. These scenarios were designed to promote discussion on the best methods of dealing with prevailing economic circumstances. Implicit in the scenarios was the notion that only by controlling wage increases could the Government hope to regulate the economy along constructive lines. The scenarios, intended to cover the period 1983-86 were:

(1) Scenario A (Medium wage path). This scenario assumed a 3 percent pay rise in the latter half of 1983 but with no catch-up for the price increases during the freeze. The scenario assumed the introduction of full quarterly indexation with provision for productivity increases from 1985 .

(2) Scenario B (High wage path). This assumed that the wages pause would cease in June 1983 and that full catch-up would be paid for price increases up to that time (approximately 5.5 percent). It assumed the introduction of full indexation from August/ September 1983 with annual productivity reviews from 1984.

(3) Scenario C (Low wage path). This scenario assumed the effective extension of the wages pause until April 1984 with the last 6 months of this freeze being partially offset by half indexation. Partial indexation would take place every 6 months providing for a maximum of 80 percent of price increases being passed onto wage and salary earners. Annual productivity reviews would commence in 1985. 
By introducing these three scenarios the Government effectively shaped the nature of the discussion which followed and this set the tenor of the conference. The Treasurer elucidated on the economic and industrial relations attributes of each approach leading to the conclusion that scenario A was the preferable option. The ACTU concurred with this view.

Unlike the unions which were represented by the ACTU Executive, employers were invited to the conference either because of their institutional positions within major employer organisations, or because of their company positions and thus appeared in their own right. Not unnaturally this made it more difficult to co-ordinate the employer viewpoint. The CAI, which could have been expected to perform a leadership role, found itself in conflict with many of the employers present. It is reasonable to assume that those invited in their own right were overcome by the occasion and were prone to making concessional statements in relation to wages and employment conditions, which the more professional and expert negotiators from the Confederation had to diffuse. This gave the CAI the image of being the only group not prepared to make concessions in the national interest. In view of the apparent, rather than real, nature of the union concessions this was not the case. Euphoria, however, rather than balanced judgement, became an important part of the Summit atmosphere.

For all the hostility engendered against it, the CAI scored a major success in restraining the joint statement presented by employers which was arrived at after several hours of consideration in camera. In this they resolved to oppose any return to the use of the consumer price movements as the basis for adjusting wages, notwithstanding claims by the ACTU that such a policy could only result in bitter industrial disputation. However, no doubt disenchanted with the results of the so-called decentralised wages system which operated in the post indexation period, employers did agree that it was appropriate to return to a centralised system of wage determination. This meant that all major parties at the conference where in agreement that a centralised system of wage determination was desirable.

Though a useful forum for demonstrating the goodwill of the new Government towards the corporate sector and as a public relations exercise, few of the areas agreed upon in the final Summit Communique afforded sufficient detail to provide a blue print for future action. Thus, in the area of wages the Communique notes:

The Summit stresses that the Conference was never intended as a forum to negotiate the timing or quatum of wage increases. It is accepted that this is a matter for the Australian Conciliation and Arbitration Commission.

All parties believe that the principles of wage fixation should be to provide wage justice to employees whilst seeking to ensure that wage increases do not give added impetus to inflation or unemployment.

It is believed that a centralized approach to wage fixation is the most equitable means by which the objectives can be met. It is recognised that if a centralized system is to work effectively as the only way in which wage increases are generated, a suppression of sectional claims is essential except in special or extraordinary circumstances proved before the centralized wage fixing authority.

This summit therefore proposes that the parties should as a matter of priority develop the option of a return to a centralized system under the auspices of the Australian Conciliation and Arbritration Commission.

The thrust of these resolutions is that of a high degree of unanimity concerning wages policy. Such unanimity is more apparent than real. While there is general agreement concerning the desirability of a centralised wage fixing system, there is no indication as to the nature and rules regulating that system. This has been placed in the "too hard" basket and left for the Commission to determine - a situation very little different from that prevailing before the Summit Conference was called. 


\section{The return of indexation}

In view of the election of Labour to office and the Accord, is it not surprising that the ACTU would seek a return of wage indexation. In June 1983, when the wages freeze came up for review, the union movement pressed for the introduction of wage indexation and for wage increases of 4.3 percent to compensate for price movements in the March and June quarters of 1983. Indicating the changed political climate the ACTU was supported by all mainland governments with the exception of Queensland and the Northern Territory. Tasmania also opposed the claims.

The CAI, while supporting a return to centralised wage fixing, opposed a centralised system based upon price movements and further claimed that such a system ought not be introduced until the end of 1983.

In reaching its determination, the Commission noted the 3 significant developments which had taken place since the introduction of the freeze. These included the Accord and National Economic Summit Conference already described and which both supported a centralised system of wage determination, and the President's Conference following the Summit Conference. In response to requests from the ACTU and CAI arising from paragraph 22 of the Communique cited above, the President chaired a 4 day conference of the major national wage parties. This conference attempted to determine those areas of agreement and disagreement concerning a wage fixing system. A subsequent Report itemised 23 issues dealt with and summarised the outcome on each of these issues. As with the Summit Conference, the parties agreed on the desirability of a centralised system but could not agree upon how such a system ought to operate. Consensus was reached, however, by the CAI, ACTU and Commonwealth in 17 areas (ACAC, 1983a, p.11). Though, in the final analysis the Commission still had to determine the form of centralised system to be introduced, this degree of consensus in a large range of areas did make its task easier. These factors, together with the Government's prices and incomes policy and assurances from the ACTU in relation to "non-conformists" pursuaded the Commission "that it would be in the public interest ... to try once again to operate a centralized system based upon prima facie full indexation ... in the expectation that it would lead to a more stable industrial environment and that it would provide the basis for a more rapid economic recovery than would occur in any alternative system" (p.16). On September 23 , nearly 3 months after the case opened, the Commission granted the wage increases sought by the ACTU and instituted a new set of indexation guidelines. These are outlined below.

The indexation principles

\section{National wage adjustments}

The principles provided for bi-annual wage adjustments on account of movements in the 8 Capitals Consumer Price Index (Darwin and Canberra having been added to the previous 6 Capitals CPI). The Commission will normally sit in the months of February and August following the publication of the CPI figures for the months of June and December respectively. The form of indexation will be uniform percentage indexation "unless the Commission decides otherwise in the light of exceptional circumstances". No provision is made for the automatic indexation of overaward payments but Principle 1 (d) provides that it would be appropriate "for the Commission, after hearing the parties to an award and being satisfied that a proper case has been made out" to recommend overaward indexation. There are to be no wage claims on account of national productivity increases until 1985. 


\section{Commitment to the principles}

To benefit from national wage cases unions must give an undertaking to abide by the Principles. Where unions do not given such an undertaking their relevant awards are not to be indexed.

\section{Work value changes}

As with previous indexation guidelines the Mark VI version provide for wage increases (in addition to those granted to compensate of CPI movements) on account of changes in work value. Principle 4(a) defines these as changes arising from "changes in the nature of the work, skill and responsibility required or the conditions under which work is performed". This Principle notes that "changes in work by themselves may not lead to a change in wage rates. The strict test for an alteration in wage rates is that the change in the nature of work should constitute such a significant net addition to work requirements as to warrant the creation of a new classification". This addition to the Principle 4(a) is no doubt intended to lessen the possibility of a "work value" wage round similar to that which occured in 1978-80. Further restriction to this Principle designed to ensure that it does not become the vehicle of generalised wage movements include:

(1) Wage increases on account of work value may only be applied to employees who have been reclassified or, where reclassified is not appropriate, preferably by way of changes in award allowances.

(2) The datum point for measuring changes in work value may not pre-date January 1 , 1978.

(3) Comparative wage justice is to play a limited role in such exercises. It may not be used in itself to demonstrate the need for wage adjustments. Once work value changes have been identified, however, comparative wage justice may be used to indicate the monetary adjustments which might be appropriate.

(4) Members of the Commission are warned against contrived classifications and overclassifications.

(5) Where, because of technological or other changes, the impact of work value on the workforce is widespread or general, the matter is to be pursued as a productivity rather than work value case.

\section{Standard hours of work}

Because of the general movement from the 40 standard hour working week which followed the Metal Industry Agreement of December 1981 and which was still being processed through the Commission, the Full Bench considered it necessary to give some guidance as to the handling of such cases within the indexation framework. The guidelines provide that:

(1) Opposed claims are to be rejected;

(2) Agreements and unopposed claims are to be scrutinised to ensure that the cost impact is negligible. Unions are required to offer cost offsets to the implementation of a 38 hour standard week;

(3) Claims below 38 hours, even if accompanied by full cost offsets, are not to be allowed;

(4) Productivity bargaining is not to be the basis of reduced working hours or other award improvements. 


\section{Anomalies and inequities}

Where special and extraordinary circumstances exist these are to be resolved by anomalies conferences to be heard by Full Benches. These should safeguard against relying on comparative wage justice. The same procedure should apply to inequities, situations "where employees performing similar work are paid similar rates of pay without good reason":

\section{Paid rates awards}

Paid rates awards are those in which the former overaward component has been brought into the award. Under an indexation regime this means that the previous overaward component is indexed. This creates the potential for discontent as employees on minimum rates awards compare their lot with those under paid rates awards. Principle 7 attempts to provide some guidance in this area which complements the guidance in relation to the adjustment of overaward payments. In general, members of the Commission are to refrain from making any new paid rates awards. Claims for the adjustment of existing paid rates awards "to establish an equitable base" are to be processed as anomalies.

\section{Allowances}

The guidelines provide for the periodic adjustment of existing allowances "which constitute a reimbursement of expenses incurred". New allowances may only be awarded to compensate those expenses not already reimbursed.

\section{The National Wage Case, April 1984}

This was the first national wage case to be held following the introduction of the new indexation guidelines in September 1983. Hearings in respect to wage increases on account of the Consumer Price Index movements for the September and December 1983 quarters began on February 28 th and, after 9 sitting days (a short period by national wage standards) concluded on March 16th. The Full Bench handed down its decision on April 4th. The September 1983 and December 1983 quarters CPI had increased by 1.6 percent and 2.4 percent respectively, and the ACTU argued for full indexation for the compounded increase of 4.1 percent. In this it was supported by the Commonwealth, all the state Labour Governments (I.e. Western Australia, South Australia, Victoria and New South Wales). It was opposed by the CAI on behalf of private employers generally, the state of Tasmania, the Northern Territory and several employer bodies which have imputed that the CAI has not been sufficiently forceful in opposing indexation. These represented the Australian Chamber of Commerce, mining interests and farming interests. The state of Queensland opposed full indexation. It favoured plateau indexation based on $\$ 256$ per week, this figure being the average weekly award rate for January 1984. Implicit in the Queensland submission was that salaries above the suggested threshold should be compressed, an area in which the Commission came to grief in 1976 and 1977.

Private employers stressed the fragility of the economy, the devasting impact wage increases could have on the embryonic recovery, the inflationary and unemployment effects of such increases and the lag in private investment, a portent of future problems. The mining industry presented a gloomy picture of that sector with depressed world prices, severe international competition and no expectation of any "substantial" pick-up in profits before 1985. Farming interests argued that an "exceptionally good season" was necessary to remove the "drought legacy of debts and restocking". 
Supporters of full indexation adjuced many indicators to suggest economic recovery was well under way. Unemployment had fallen from 10.3 percent in June 1984 to 9.4 percent in February 1984 and over the same period civilian employment had risen by 1.8 percent. Advertised job vacancies had risen as had real private consumption. Interest rates continued to fall, the profit share had risen and both Farm and Non-Farm Gross Domestic Product grew strongly.

The Full Bench concluded that the material before it "made it clear that although there had been a recovery, although this recovery had been somewhat faster than was anticipated 6 months ago and although investment expectations have been revised upwards, the recovery is still in its infancy" (ACAC, 1984, p.7). On economic and other grounds, however, the Bench felt that full indexation was justified. Concerning the depressed mining and rural industries the Bench noted that:

it should be understood that, this being a national wage case, (specific industry material) is only relevant in so far as it throws light on the overall state of the economy. Economic incapacity in relation to particulary industries is a matter for consideration in relation to particular award adjustments (p.8).

This remark may well have been directed to the futility of sectional employer groups fragmenting the CAI (as the rural sector has done) in the expectation of getting for their members better results at national wage cases. The Bench has reminded such groups that the appropriate time to argue the case for the inability of a particular industry to pay national wage increases is when individual awards are varied in line with national wage adjustments. This provision was specifically provided for in the September 1983 decision in which the Bench noted:

\begin{abstract}
While we would not debar argument being advanced on economic incapacity we would emphasize not only the long established principle of wage fixation that those seeking to argue incapacity to pay must present a strong case, but also that the fundamental basis of a centralized system is uniformity and consistency of treatment. In particular in cases involving the adjustment of rates in line with national wage decisions the Commission should not refuse an increase except in extreme circumstances (ACAC, 1983, p.19).
\end{abstract}

A second reason for which employers argued that indexation should not be granted related to lack of commitment to the principles. Such argumentation concerning the lack of "substantial compliance" formed an important part of the previous indexation regime. Of particular interest were developments in the construction industry in which unions had transformed a $\$ 9$ above indexation claim into one for the introduction of superannuation in the industry. The ACTU rejected this contention. The claim was isolated to 1 industry and sought to remove a situation where a particular group of employees were not entitled to an employment benefit generally available to other employees. Of more importance was the situation in the food preserving and confectionary industries in which the unions had refused to give the appropriate undertaking required by the guidelines. In several instances employers had granted the appropriate wage increases after assurances from their own employees that they would abide by the guidelines. Such wage increases could not receive the Commission's consent and so could not be incorporated into awards. The CAI requested that in such circumstances the Commission should vary awards in relation to specific establishments where it was satisfied that the undertaking given by the employees was genuine. "It is regrettable", the Bench commented,

that the unions concerned did not see fit to give their members award protection by declaring their commitment to the Principles as required in the spirit of the Accord to which they are party. But .... the provision sought by the CAI would allow a piecemeal application of national wage increases in a way which could undermine the responsibility of particular unions and of the ACTU in ensuring that the Principles are adhered to. Moreover, we should not do anything to weaken the longstanding convention that the Commission should deal with unions rather than individual employees. (ACAC, 1984, - p.14). 
As already noted the Queensland submission sought plateau indexation. This received little support from the Commission which, on the basis of previous experience, had provided under Principle 1(c) for uniform percentage adjustments unless exceptional circumstances existed. It has also been noted that the September 1983 Principles indicated that full indexation would be the norm. In this case the CAI made a lengthy submission arguing for the discounting of Government charges and tax induced CPI increases. In rejecting this the Bench reaffirmed its commitment to full indexation. "The adoption of the CAI's reasoning on this question", it claimed, "could well lead to partial indexation on a regular basis, an approach which would be inconsistent with the concept underlying the present indexation package". For good measure it added: "Further, we believe that to interfere with the CPI by way of discounting, even if justified on economic logic, may reduce confidence in the present system and weaken commitment to it" (p. 12).

In granting full indexation on this occasion there is little doubt that the Full Bench was as much motivated by the Accord as it had been when implementing the September 1983 Principles. The arguments before it, the Bench claimed, "are essentially similar to those facing the Commission in its deliberations leading to its decision of 23 September 1983" (p.10). It added that it was "moved by the same considerations" as in the earlier case (p.11). These considerations included the Government prices and incomes policy "described as the corner-stone of economic policy"; the Accord, regarded as "a major anti-inflationary instrument" by the Treasurer; the endorsment of "an effective prices and incomes policy" and a centralized system of wage determination in the Summit Communique; and the fact that the package had been formulated for a period of 2 years and should be given a fair run during that period.

Full indexation was granted with the pay increases to become effective from the first pay period to commence on or after April 6th 1984.

\section{The future}

The Accord has now been in operation for 15 months. Despite frequent media pontification concerning its near demise it has displayed that degree of stability, and elicited sufficient commitment, to suggest that it will continue to be the major vehicle for economic and industrial relations policy at least until the expiration of the present 2 year indexation package (i.e. until September 1985). Though indexation can survive without the Accord, such a survival is likely to become a replay of the 1976-1981 period when, stripped of the supporting mechanisms, the indexation framework came to resemble a Tower of Babel. In the light of previous experience it is unlikely that the Commission will persevere with such a demanding set of Principles in the absence of demonstrated support from the incumbent government.

At the time of writing the Accord has not only confounded the critics who saw in it little more than an election ploy but has demonstrated its effectiveness. Unions have not broken the undertakings demanded of them by the Principles and the one major recalcitrant union - the BLF - has been forced by the ACTU and other building industry unions to give up its demands for payments of $\$ 9$ per week in excess of the 4.1 percent increase awarded in April. Other building unions were forced to abandon a similar claim when the Commission refused to ratify an agreement to that effect which they had concluded with the major construction employer associations. Further, indexation and the Accord have been accompanied by, or have induced, the lowest level of strikes in 16 years. Avoidance of industrial disputation was a major component of the "substantial compliance" requirement under the previous indexation regime. In addition the Government has successfully introduced Medicare. In so doing it has forced Queensland to back away from its threatened boycott; private practitioners under contract to public hospitals to give up their alleged right of control over such contracts; and the AMA to accept the decisions of the Medical Benefits Tribunal this helping satisfy part of the Accord require- 
ment of controls over non-wage and salary forms of income. The Government has also successfully brought the decisions of the Remuneration Tribunal into line with those of the Commission, thus removing a major grievance which operated under the previous indexation system, where the Government argued before the Commission that the economy could not afford full indexation for wage and salary earners, but also argued before the Remuneration Tribunal for full, (and in many cases above, CPI increases) for federal politicians. The Government has also brought pressure to bear on the South Australian and Tasmanian Legislatures which have received abnormally large salary increases since the March 1983 elections.

The Government's approach has been aided by the improved communication channels with ACTU by way of the Australian Labour Advisory Committee and by the affinity of outlook between Hawke and key figures in the ACTU. The enlargement of the ACTU Executive as the result of structural changes following the absorption of the former white collar union peak council (the Australian Council of Salaried and Professional Associations) and the intended absorption of the Council of Australian Government Employee Organisations has meant that the majority of key unions are now represented on that Executive. Thus they are more amendable to peer group pressure and more likely to be supportive of those policies in which they have had an input. In respect to both the Accord and indexation, the ALP and ACTU have been assisted by the general support of unions ranging the ideological spectrum represented within the ACTU. Indexation has also been assisted by the requirement that individual unions give an undertaking to adhere to the Principles and thus forcing would-be delinquents to face the ACTU opprobrium. ${ }^{1}$ In addition to Medicare, other supportive measures which the Government has put into train has also helped induce union support. These include the establishment of the Prices Surveillance Authority whose real effect might by pyschological rather than instrumental; the lowering of the migration ceiling to 80,000 per year, including a halving of the intake of the previous level of "skilled" labour and those on working holidays; the repealing of the CEEP Act which provided for the compulsory retrenchment of certain classes of public employees and the amendment of the CERR Act which previously provided for "management initiated" retirement of public employees. Economic recovery has also assisted by reducing the number of dependent upon unemployment benefits and increasing the number of employees contributing to the taxation coffers. This will make it easier for the Government to provide taxation concessions which form an integral part of the Accord. Most importantly the Accord has been aided by the high level of trust between the union movement and the Government, a situation which contrasts starkly with relationships under the Fraser Government. The greater assurity of full indexation provided by the existing guidelines has also been of value as has the effective locking-in of employer organisations into the indexation regime.

Another factor aiding the existing indexation system is the high proportion of the members of the Commission with little experience in their roles as conciliators and arbitrators other than under an indexation regime. Thus the sorts of challenges which came from the members of the Commission in the 1975-1981 period are not likely to be replicated. Further, changes to the Act in 1979 have removed the ability of Commissions to move outside the indexation framework ${ }^{2}$ while a mechanism has been established to quarantine more independently minded presidential members. ${ }^{3}$

1. The Food Preservers Union which attempted to justify its breach of the Accord at the 1983 ACTU Congress was severely criticised by both left wing and right wing unions at this Congress.

2. Before varying awards Commissioners are now required to "consult" with the Deputy President in charge of the relevant Panel.

3. The number of Deputy Presidents now exceeds the number of Industry Panels. This has resulted in one Deputy President being consigned exclusively to Full Bench matters. 
Helpful as these factors may have been during the initiation and infancy stages of indexation they do not assure longevity to the Accord or the Principles. In fact each of the factors may prove to be potential sources of assistance and pressure. It may be useful to look at the possible pressures in terms of the short term, the medium term and the long term.

\section{The short term}

By the short term is meant the period until the expiration of the existing Principles, that is until September 1985. By then it is likely that an early federal election will not have been held and the ALP confirmed in office for a further 3 years.

Some of the short term potential pressures eminate from the Principles themselves. These, for example, require unions to give an undertaking that they will uphold the Principles. Two potential threats are apparent in this respect. The first concerns the way in which the Commission might deal with unions which give the undertaking but which also indulge in activities inconsistent with the guidelines. Presumably the response would be to refuse to vary the appropriate awards following the subsequent national wage case. As such unions are likely to have the muscle to win in the field what they have been denied in the Commission, such a sanction is not likely to be effective and would merely highlight the Commission's lack of enforcement powers. Indexation thus continues to exist on the basis of fragile union consensus.

The second threat relates to unions' refusing to give the necessary undertaking. To date only 2 small and insignificant unions in the food preserving and confectionery industries have refused to give the undertakings required by the Principles. Their awards have not been indexed. The system had coped adequately with this situation. A more difficult situation would be presented if major intra-industry unions (such as, for example, those covering metal workers or transport workers) were to refuse to give the necessary undertaking. In such a situation it would be difficult to see how indexation could survive in its present form. An even more problematic situation would be one in which any 1 union party to a consolidated award refused to give the undertaking. For example, there are 8 union respondents to the Metal Industry Award. Should any one of these unions not give the undertaking, then all employees under that award would be denied wage indexation. Thus a small union, with a relatively insignificant membership under this award such as the Gasfitters' and Plumbers' Union, is in a position where it can veto the indexation of wages for over 300,000 employees. In this and similar situations a small, anti-Accord or anti-indexation union has the potential to bring about a crisis which may destroy the system.

A further potential source of difficulty arising from the guildelines is that individual industries are entitled to oppose award variations in line with national wage adjustments on the grounds of incapacity to pay. The economic logic behind such a contingency is indisputable. The industrial relations implications of select groups such as shearers or miners being denied national wage increases on the grounds of a lack of industry capacity to pay are disquieting. As noted earlier in this paper, some employer groups, notably the National Farmers' Federation, the Australian Mining Industry Council and the Australian Chambers of Commerce have taken a harder line to indexation than they have perceived to be the case with the CAI. The National Farmers' Federation has disaffiliated from the $\mathrm{CAI}$ and, as with the other organisations, was separately represented at the last National Wage Case. It is thus most likely that these bodies will vigorously oppose national wage increases to those awards coming under their sphere of influence.

A major short term problem relates to the "tax bite" which reduces the effectiveness of indexation in maintaining real standards of living. Because indexation has also pushed increased earnings by many beyond the 30 percent taxation bracket and into the 46 percent bracket, indexation has also been an effective method of reducing real dis- 
posable income without explicit action on the part of the Government. The 4.1 percent wage increase awarded in April 1984, for example, placed an estimated additional 210,000 employees, or an additional 3.4 percent of the workforce, into the 46 percent bracket. (Sydney Morning Herald, 9/4/84, p.17).

Allied to the taxation problem is that arising from the "doctoring" of the CPI as the result of the introduction of Medicare. This form of medical insurance has resulted in a 1 percent levy on personal income tax for "basic" medical public hospital care. Those seeking cover against other health costs have had to take out further private insurance costing about $\$ 16$ per week in the case of family cover. Because basic health insurance is now Treasury financed, the medical component has been omitted from the CPI for indexation purposes. The net effect is that although workers are still paying for health services either by way of the income tax levy and/or private health insurance, this cost component will not be compensated for in future national wage cases. An even more immediate problem will be that the removal of the health component from the CPI may result in a CPI increase of less than 1 percent for the first half of 1984. Consistent with earlier practice, the Commission may decide not to hold the National Wage Case scheduled for August under such circumstances, thus resulting in an effective wages pause of 12 months (i.e. from April 1984 when the last National Wage Case concluded to April 1985 when the National Wage Case for the September 1984 and December 1984 quarters will have been processed). It is unlikely that unions will sit by idly in such a situation and already the portents are that they will use this period as a "catch-up" one to press for compensation for the 9.1 percent real wage reduction experienced during the wages freeze/pause. Eighteen left wing unions have already made demands for a "catch-up" claim in the order of 3.1 percent. This claim will be put to the Wages Policy Committee of the ACTU in late May when this Committee is due to confer with the Government over taxation.

Some have hailed this move as a breach of the Accord. Whether or not it proves to be so depends upon the way in which such "catch-up" is pursued. The Accord specifically provides for the restoration of the foregone 9.1 percent "over time". Should the 18 unions resort to unilateral action in pursuit of their claim then the Accord will have been breached. Other methods of achieving the "catch-up", for example under the productivity provisions of the Principles (which would require waiting until at least September 1985) or by way of tax concessions, would not be inimical to the Accord or indexation. The fact that the 18 unions concerned have taken their claim to the ACTU in time for that body to take the matter to Government indicates that those unions are not prepared, at least at this point in time, to jettison indexation.

The Accord has shifted much of the attention over wages to Union-Government relations as opposed to Union-Employer relations. This is as it ought to be. Employers (and the Commission) may have some influence in relation to the real wage but have little control over real disposable income or the "social" wage. Elsewhere I have attempted to demonstrate the futility of unions pressing for the indexation of wages under a system where the Government is in a position to frustrate union aspirations. In the period March 1975 to June 1982, for example, the Carpenter and Joiner Classification under the National Building Trades Construction Award (a classification which in 1982 approximated the AWE figure) received wage increases in the order of $\$ 184$ per week. Over the same period wage imposts in the form of direct and indirect taxation exceeded $\$ 210$ per week (Plowman, 1983 p.423). Thus the existing situation in which unions and governments are bartering over real disposal incomes may be a more productive one for unions. Already the ACTU and the Government have fired their opening salvos which some journalists have interpreted as (yet another) breakdown of the Accord. A more reasonable interpretation is that both parties have established some form of "ambit". The ACTU Wages Policy Committee has announced its "long term taxation expectations". These include a broadlybased wealth tax; a capital gains tax; a "review of the system so that taxes do not automatically rise with inflation"; a broadening of the tax base; and a tax on "excessive profits where appropriate" (Australian 24/4/84:3). For his part the Minister for Employment and Industrial Relations has publicly voiced concern that tax cuts could be 
threatened if any wage claims are made before the budget is finalised. Fortuitously the budget is usually announced in the month of August, the month the next national wage case is due.

Though there is an element of ambit negotiations in these exchanges problems on the taxation front can be expected. In the short term the major problem will relate to the level of taxation relief. To satisfy the ACTU and to foreclose on "catch-up" demands in August, the Government will need to make good the "tax bite" out of the indexation decisions since September 1983 (i.e. "full tax indexation") as well as make some compensation for the CPI discounting as the result of health insurance changes. Unions have been quick to point out the price of vegetables are no lower as the result of the artificial deflation of the CPI. For the "average" weekly wage earner full tax indexation will represent tax cuts in the order of about $\$ 10$ per week. The Government may also be forced to raise the 46 percent marginal taxation threshold from the existing figure of $\$ 19,500$ to remove the increased marginal rate of taxation on middle income earners accompanying indexation. In addition some formula will also have to be agreed upon to compensate for the estimated 2.8 percent discounting of the CPI as the result of Medicare. Whether or not the Government is prepared to give tax concessions of this magnitude remains to be seen. A related problem is whether or not unions will accept tax cuts as a substitute for the real wage losses under the wage freeze and so discount their 9.1 percent catch-up claim. Though there is no logic for not accepting such an exchange, the symbolism enshrined in real wage maintenance may prove too strong for some unions and highlights yet another longer term potential difficulty. Though tax concessions may be good for "keeping the peace" they (and indexation itself) do little to promote union officials' image of front line wage fighters. Further tax cuts may enhance the election prospects of Governments but do little to enhance the prospects of union officials who must also face their constituencies. In the longer term union officials may feel compelled to move into new areas of activity to counteract the impression that wage improvements are merely by way of Government and Commission fiat. Such excursions may threaten the Accord. A similar situation may arise from state industrial tribunals attempting to assert their autonomy in relation to the wages of state award employees.

In the short term one may also expect increasing strains resulting from the all-embracing nature of the Accord. Unions will feel (and have already suggested) that the Accord effectively binds the Government to ACTU policy and gives them a veto over Government activities. The AMFSU, for example, has claimed that the Government's intention to deregulate banking is in breach of the Accord, ostensibly because meaningful negotiations have not been entered into with unions over the issue. No Government can afford to be so circumscribed, particularly when "meaningful negotiations" are interpreted to mean that unions get their own way. The mining or uranium will provide another area of conflict as may the question of immigration.

\section{The medium term}

By the medium term I mean the period to the end of 1987. During this period the pressures already outlined may be expected to have increased in intensity. Further, if analysts are correct in their assessment of the economic situation, by then unions as a whole may be provided with a real alternative to wage indexation which, good as it may be in maintaining real wages, does little to improve those wages. Contrary to some analysts I do not predict that improved economic conditions will automatically result in a "movement away from arbitration" as occurred in the mid 1960s. If such a movement is to occur, the economic conditions will provide a necessary but insufficient condition for such a movement. The most compelling factors will be whether or not the union-government trust relationship holds out and whether or not the centralised system is seen to be providing a fair return to labour. In such a context full indexation will not be sufficient and will have to be augmented by wage increases on account of national productivity movements. The Mark
VII Principles will need to provide for such a contingency. 
The period may also see increasing problems as the result of some awards being paid rates awards and other minimum rates awards. The guidelines do not offer any long-term solution to this problem and perceived relativity erosion on the part of employees on minimum rates awards can be expected to intensify.

\section{The long term}

Beyond 1987 the pressures alluded to in earlier time periods can be expected to have increased. By then too, the original visions and intentions of the Accord partners may have become blurred by the efflux of time. (Alternatively, of course, a successful partnership may result in a greater willingness to pursue the prices and incomes strategy underlying the Accord). The Accord may also have become dulled by the cummulative weight of those "exogenous" factors which journalists continually find as threatening to the Accord. Current "exogenous" factors may help illustrate this point. It is to be expected, for example, that redundancy problems on the waterfront, where some 800 jobs are to be shed in the first half of 1984 , and where those being retrenched are confronted with a lottery involving 3 different methods of computing redundancy payments, will be accompanied by disputation. It also is to be expected that building and other workers who do not have access to superannuation will press for this generally available condition of employment. It is also to be expected that the vagaries of the dual system of federal and state tribunals will lead to glaring anomalies such as in the electricity generating industry in New South Wales where supervising engineers under federal awards are paid less than those state award employees they supervise. In situations where employers refuses to acknowledge the existence of such anomalies, disputes are inevitable. These, and similar situations, will continue to occur and require amelioration irrespective of the existence of the Accord or indexation. A danger exists that the Accord may become the victim of self-fulfilling prophecy as such activities are seen as evidence of a breakdown. Further, the Accord may disintegrate because of the unrealistic expectations placed on it. Such observations, however, may underestimate the Accord's resilience.

The medium and long terms may be expected to be periods in which opposing political approaches will be heightened as was the case preceeding the 1983 elections. Though the ALP has built its economic policy around centralised wage fixing and an incomes policy approach, it would be wrong to think that should the Accord fall apart the Labour Government will be left with no arrows in its quiver. Such an assessment would under-rate the Government's pragmatism and instinct for survival. Both Hawke and the former ALP leader (Hayden) have warned that in the absence of union co-operation a Labour Government would employ the "blunt unselective economic tool of monetary and fiscal policy" (Cupper, 1982, p.126).

Confronting the Labour approach will be the alternative presented by the Liberal Party's newly adopted Policy on Industrial Relations. This policy seeks a "system of dispute settlement and wage fixing which is sensitive to economic conditions" (p.3). To achieve this a "radical but realistic overhaul of the system from within, involving the creation of a new tribunal with the power to fix minimum wages, settle disputes, enforce decisions, and assist positively in the restructuring of the trade union movement" is proposed. The new tribunal would not have the power to make paid rates awards; wages would not be adjusted to prices but rather to productivity; and the only other circumstance in which award wages would be varied would be in the case "of a demonstrable change in the work value of a particular job" (p.4). The tribunal would not be able to "make an award granting annual leave loading, allowances such as site allowance, or superannuation" (p.5). In short, the tribunal would establish only minimum standards forcing the parties to enter into "collective bargaining" over other matters.

This is not the place to debate the merits or demerits of the Liberal Party's policy. As with the implementation of the Accord, in the final analysis it will be the electors who will decide whether or not the Coalition will have the opportunity of implementing its new policy which would appear to be an electoral liability. 


\section{References}

Australian Conciliation and Arbitration Commission (1982a) National wage case, reasons for decision.

Australian Conciliation and Arbitration Commission (1982b) National wage case, reasons for decision.

Australian Conciliation and Arbitration Commission (1983) National wage case, reasons for decision.

Australian Conciliation and Arbitration Commission (1984) National wage case, reasons for decision.

Australian Council of Trade Unions (1983) Statement of Accord.

Cupper, L (1982) The 1981 ACTU Congress: consolidation, consensus and co-operation(?), The journal of industrial relations 24(1).

Plowman, D H (1981) Wage indexation a study of Australian wage issues 1975-1980, Allen and Unwin, Sydney.

Plowman, D H (1982) Indexation and beyond: Australian wage determination 1978-1982 New Zealand journal of industrial relations, 7(3):189-204.

Plowman, D H (1983) Unions and incomes policies: indexation and beyond: (In) Ford $\mathrm{GW}$ and Plowman, D H (Eds) Australian unions an industrial relations perspective, Macmillan, Melbourne: 412-434. 